〈연구논문(학술)〉

$$
\begin{gathered}
\text { 용매에 따른 MWNT의 분산특성과 제조된 PU/MWNT 필름의 } \\
\text { 전기적 - 물리적 특성 분석 }
\end{gathered}
$$

김정현 · 마혜영 · 양성용 · 김승진 ${ }^{\dagger}$

영남대학교 섬유패션학부

\title{
Analysis of Electrical and Physical Property of the PU/MWNT Film and Dispersion Characteristics of MWNT According to the Solvent
}

\author{
Jeong Hyun Kim, Hye Young Ma, Sung Yong Yang and Seung Jin Kim ${ }^{\dagger}$ \\ School of Textiles, Yeungnam University, Gyeongsan, Korea
}

(Received: November 30, 2011/Revised: December 14, 2011/Accepted: February 3, 2012)

\begin{abstract}
This paper surveys the physical properties of the MWNT dispersion solution dispersed with the three types of solvents and of the polyurethane composite film for improvement of mechanical properties and electrical characteristics of PU/MWNT composite film.

For this purpose, the MWNT dispersed solution was mixed with three types of solvent such as IPA, MEK and Toluene and then mixed with polyurethane (100part) with variation of loading content $(0,10,20,30,40,50$ part) of MWNT dispersed solution in the ultrasonic wave dispersion apparatus. And eighteen PU/MWNT composite films were prepared as specimens. The various physical properties of these PU/MWNT films were measured and discussed with the loading content of three types of MWNT dispersed solutions. The highest absorbancy among the three types of dispersed solutions was shown in the IPA/MWNT solution. But the absorbancy of PU/MWNT films was not same as the solution. The low electrical surface and volume resistivity of PU/MWNT film were shown at the condition of 20 and 10 parts loading of IPA/MWNT dispersed solution, respectively. The low triboelectricity of PU/MWNT film was shown at the condition of above 30part loading of IPA/MWNT dispersed solution. The breaking strength and strain of PU/MWNT film prepared with IPA/MWNT dispersed solution were decreased with increasing loading content of IPA/MWNT from 10 to 40 parts. The maximum breaking strength and breaking strain according to the dispersion solution were shown on the IPA/MWNT dispersed solution. The uniform dispersion of PU/MWNT film according to the loading content of MWNT solution was shown by surface image analysis on the films dispersed with IPA.
\end{abstract}

Keywords: IPA, MEK, toluene, MWNT, solvent

$$
\text { 1. 서 론 }
$$

나노기술(Nano Technology, 이하 NT)은 21세기를 주도할 6대 혁신기술 중 하나로 IT(Information Techno$\operatorname{logy}$ )와 BT(Bio Technology)의 기반기술이며 현재 이 에 대한 관심이 고조되고 있다. 현재 나노 소재중 가장 주목을 받고 있으며 다양한 부분에 걸쳐 응용 가능성을 시험하고 있는 것은 탄소나노튜브 $(\mathrm{CNT})$ 로 1991년에 일본 NEC(일본전기회사)의 수미오 이지 마(S. Iijima)에 의해 처음으로 발견되어 발표되었으 며 이는 나노기술을 비약적으로 발전시키는 계기가 되었다.
탄소나노튜브의 완벽한 물성과 구조는 전자정보 통신, 환경, 에너지 및 의약 분야 등 폭넓은 분야에 서 응용이 기대되는 소재로 여겨지고 있다. 탄소나 노튜브는 튜브형상을 이루는 벽의 수에 따라 단일 벽(Single-walled, SWNT), 이중벽(Double-walled, DWNT), 다중벽(Multi-walled, MWNT)으로 구분하고 있다. $\mathrm{SWNT}$ 의 경우 직경이 $1 \mathrm{~nm}$ 수준에 불과하여 단독으 로 존재하지 못하고 van-der-waals 인력에 의한 응 집현상이 발생하여 수십-수백 $\mathrm{nm}$ 의 번들 형상으로 존재하며 MWNT의 경우는 상대적으로 직경이 커 서 응집현상보다는 고분자 사슬의 엉킴현상과 유사 한 특성을 보여준다.

\footnotetext{
${ }^{\dagger}$ Corresponding author. Tel.: +82-53-810-3890; Fax.: +82-53-812-5702; e-mail: sjkim@ynu.ac.kr

(c)2012 The Korean Society of Dyers and Finishers 1229-0033/2012-03/69-78
} 
DWNT의 경우 직경이 작은 일부는 SWNT와 유 사한 특성을, 직경이 큰 일부는 MWNT와 유사한 특성을 보여준다 ${ }^{1)}$. 이러한 탄소나노튜브를 고분자 복합 소재로 사용하기 위해서는 번들형상 또는 엉 킴 현상 등의 응집 특성을 분산시키는 기술을 반드 시 해결해야하며 이러한 응집현상을 해결하기 위한 노력은 탄소나노튜브의 미래시장을 확장하고 가치 를 높이는데 매우 중요한 의미를 갖고 있다. 따라 서 나노튜브 응용에 있어 분산기술은 반드시 극복 해야 할 요소기술이라 할 수 있다 ${ }^{1)}$.

최근 탄소나노튜브의 분산방법이 학계를 중심으 로 많이 제시되고 있으며, 실제로 초음파처리에 의 해 탄소나노튜브의 절단, 산처리 된 탄소나노튜브 의 외부 표면에 기능화를 통한 정전기적 분산, 각 종 용매, 계면활성제, 폴리머 물질을 이용한 화학적 처리에 의한 많은 분산 방법들이 보고되고 있으며 기계적 분산처리 방법은 볼밀링에 의한 분산, 연마 와 마찰, 높은 전단력에 의한 분산 방법 등이 초음 파 처리 방법과 함께 물리적인 처리에 의한 방법으 로 분류되고 있달. 이들에 관한 많은 연구를 보면 우선 계면활성제를 이용하여 탄소나노튜브가 용액 상에서 용해될 수 있달. 그러나 계면활성제 사용 은 탄소나노튜브의 고유특성을 유지시킬 수 있는 장점을 제공하나, 추후 공정에서 계면활성제의 제 거가 큰 문제가 될 수 있으며 최대 분산농도도 약 $1 \%$ 수준에 불과하다. 김 등 ${ }^{4)}$ 은 수용성 고분자인 폴리비닐알코올 수용액에 탄소나노튜브를 분산시 킬 때 계면활성제, 초음파처리, 탄소나노튜브의 종 류가 복합용액의 유변학적 성질에 미치는 효과에 대하여 고찰하였다. 산에 의한 화학적 개질 방법은 나노튜브의 표면에 - $\mathrm{COOH}$ 그룹을 생성해줌으로써 나노튜브의 기능화를 증진시켜 탄소나노튜브가 좀 더 화학적으로 반응성이 있고 다른 고분자와 친화 력을 가져 분산이 용이하도록 해준다. 한편 김 등 5$)$ 은 화학적으로 개질한 탄소나노튜브를 이용하여 형 상기억 폴리우레탄 복합체를 제조함으로써 높은 전 기전도도와 역학적 성질을 동시에 만족시킬 수 있 는 복합체 제조에 관한 연구를 행하였고, 원 등이는 다중벽 탄소나노튜브, 계면활성제 그리고 바인더의 다양한 함량을 갖는 용액을 만들어 폴리에스테르 섬유를 침지하여 다중벽 탄소나노튜브가 코팅된 폴 리에스테르 섬유를 제조하여 그들의 표면구조와 전 기적 특성을 분석하였다. 한편, 정 등ㄱ)은 다중벽탄 소나노튜브를 이용하여 용융컴파운딩 방법으로 나 노복합체를 제조한 후 탄소나노튜브가 열가소성 폴 리우레탄 블록공중합의 물성에 미치는 영향에 대해 고찰하였고, 강 등8)은 탄소나노튜브를 동시계면중 합법에 의해 고분자 내에 복합시킨 후 전기방사에
의해 나노복합체 섬유를 제조하는 방법에 관한 연 구를 하였다. 그런데 탄소나노튜브 복합체가 전도 성을 가지기 위해서 반드시 극복해야 할 문제 중의 하나는 고분자내에 탄소나노튜브를 효과적으로 분 산시키는 것이다. 효과적 분산을 위해 많이 사용하 는 방법은 질산, 황산의 혼합용매에 의하여 탄소나 노튜브를 산처리하거나 ${ }^{9-11)}$, 탄소나노튜브 표면을 유기물질이나 고분자를 탄소나노튜브 표면에 기능 화하는 방법이 있다. 이외에 click chemistry를 이용 하는 방법, $\pi-\pi$ 상호 작용력을 도입하는 방법, 탄소 나노튜브 내외에 금속 또는 유기물질을 encapsulation 시키거나 하이브리드화시키는 방법 등이 있다 ${ }^{12-15)}$. 이중 가장 많이 사용되는 방법은 알콜류와 같은 용 매에 탄소나노튜브를 넣고 초음파 처리하여 분산시 키는 것으로 가장 단순하면서도 일반적인 방법이 다. 현재까지 탄소나노튜브를 분산시키는 최적의 용매는 수소결합 특성이 강하고 루이스염기특성이 강한 용매로 특히, N,N-dimethyformamide(DMF), Nmethylpyrrolidone(NMP) 등이 우수한 용해도를 나타 내고 있으며 Ausman 등은 다양한 용매를 이용하여 상온에서 SWNT의 용해도를 관찰하여 보고하였다 ${ }^{1)}$. 그러나 이것은 고순도의 SWNT를 특정 용매상에서 분산을 시도하였기 때문에 실제공정에서 많이 사용 되는 다양한 용매상에서의 분산특성에 관한 구체적 인 실험 및 연구결과는 아직 부족하다.

본 연구에서는 실제공정에서 많이 사용되는 분산 용매에 따른 MWNT의 분산특성을 실험하고 MWNT 가 분산되어 있는 세 종류의 분산용액의 함유량을 변화시켜 1 액형 폴리우레탄 수지와 각각 복합화하 여 제조한 필름에 대한 각각의 분산용액 함유량 변 화에 따른 전기전도성, 대전성 및 필름의 마찰대전 압과 반감기와 물리적 특성을 분석하여 정전 - 방전 $\mathrm{PU}$ 발포 필름의 1-skin 층의 적합성 여부를 본 연구 를 통해 고찰하고자 하였다.

\section{2. 실 험}

\section{1 시료}

본 연구에서 사용한 시료인 탄소나노튜브는 다중 벽 탄소나노 튜브(MWNT, 한화 나노텍, CM-95 type) 로서 CVD 방법으로 제조한 순도 $95 \%$, 길이 10 20 $\mu \mathrm{m}$, 직경 $10 \sim 15 \mathrm{~nm}$ 의 나노튜브이다. 그리고 $\mathrm{MWNT}$ 의 분산용매로는 이소프로필알코올(Isopropyl Alcohol, 이 하 IPA), 메틸에틸케톤(Methyl Ethyl Ketone, 이하 MEK), 톨루엔(Toluene)을 사용하였으며 Table 1에 사용된 3종의 분산용매를 나타내었다.

또한 MWNT/PU 필름 제조를 위해 사용한 고분 자 메트릭스는 (-NH-CO-O-)의 화학구조식을 갖는 
폴리우레 탄(Polyurethane, 이하 PU)으로 $30 \%$ PU와 $38.5 \%$ 의 디메틸포름아미드(N,N-dimethylformamide, 이하 $\mathrm{DMF})$, 그리고 $31.5 \%$ 의 $\mathrm{MEK}$ 를 혼합한 1 액형 $\mathrm{PU}$ 수지 혼합용액 PU(HI-BON 972DF, Cytec. Industries Inc.)이다. Table 2에 본 실험에 사용된 PU의 특성 을 나타내었다.

그러나 필름 제조시 사용된 $\mathrm{MWNT}$ 분산용액을 함유한 $\mathrm{PU}$ 의 점도는 $6,500 \sim 7,000 \mathrm{cps}$ 로 친수성 및 친유성을 모두 용해시킬 수 있는 $\mathrm{MEK}$ 를 사용하 여 필름 제조에 적합하도록 점도를 조절하여 사용 하였다.

\section{$2.2 \mathrm{MWNT}$ 의 분산용액제조}

MWNT를 3가지 용매에 분산시킨 혼합용액의 특 성을 Table 3에 나타냈다. MEK/MWNT분산용액은 $\mathrm{MEK} 97 \mathrm{~g}$ 에 산처리와 후처리 ${ }^{16-18)}$ 를 거친 MWNT를 $3 \mathrm{~g}$ 함유하고 분산시간을 2 시간으로 고정하여 초음 파분산기(Sonics \& Materials Inc., USA)를 이용하여 분산조건 분당 55 초 진동 후 5 초간 무진동, $750 \mathrm{watt} /$ $20 \mathrm{KHz}$ 에 $25 \%$ 출력조건으로 작업하여 제조하였다. IPA와 톨루엔(Toluene)의 경우 MEK/MWNT 분산용 액과 동일한 조건으로 제조하였다.

\section{$2.3 \mathrm{PU} / \mathrm{MWNT}$ 필름의 제조}

Table 4에 분산용매와 이들의 함량에 따른 $\mathrm{PU}$ /MWNT 필름의 제조조건을 나타냈다. MWNT가 분 산된 Table 3에 보인 분산용액 3 종의 각기 다른 함 량 $(10,20,30,40,50,60 \operatorname{part}(\mathrm{gr}))$ 을 $100 \mathrm{~g}$ 의 PU와 혼 합하고 교반기를 이용하여 교반속도 $500 \mathrm{rpm}$ 이하 에서 3 시간동안 교반시켜 총 18 종의 분산용매와 용 액함량에 따른 필름 제조용 paste를 만들었다. paste 제조시 필름제조에 맞는 점도를 유지하기위해 $\mathrm{MEK}$ 를 첨가 $(20,30,40,50 \mathrm{part}(\mathrm{gr}))$ 하여 점도를 6,500 $7,000 \mathrm{cps}$ 로 조절하였다. 또한 비교 필름으로 $\mathrm{MWNT}$ 분산용매가 함유되지 않은 Normal paste도 $\mathrm{MEK}$ 를 첨가하여 동일 점도로 제조하여 총 19 종의 필름 제 조용 paste를 상온에서 24시간 숙성시켜 용액 내부 의 기포를 제거한 후 필름 제조에 사용하였다. 제 조한 필름의 박리를 용이하게 하기 위하여 코팅지 위에 숙성된 paste $20 \sim 25 \mathrm{~g}$ 정도를 붓고 필름제조기 YBA-4형(Baker Applicator, Japan)을 이용하여 150 $\mathrm{mm}$ 두께로 캐스팅하여 분산용액.함량별 $\mathrm{PU} / \mathrm{MWNT}$ 필 름 19 종을 제조하였다. 캐스팅 된 필름의 건조는 건 조기에서 내부온도 $120^{\circ} \mathrm{C}$ 의 조건하에서 120 초 동안

Table 1. Physical properties of solvents

\begin{tabular}{ccccc}
\hline Product & Chemical structure & Specific gravity & B.P $\left({ }^{\circ} \mathrm{C}\right)$ & Flash point $\left({ }^{\circ} \mathrm{C}\right)$ \\
\hline $\begin{array}{c}\text { IPA } \\
\text { (Isopropyl Alcohol ) }\end{array}$ & $\mathrm{CH}_{3}^{\mathrm{MEK}}$ & 0.79 & 82 & 12 \\
\hline $\begin{array}{c}\text { Methyl EthylKetone) } \\
\text { TOL } \\
\text { (Toluene) }\end{array}$ & $\mathrm{CH}_{3}-\mathrm{C}_{2} \mathrm{H}_{5}$ & 0.81 & 80 & -4 \\
\hline $\mathrm{C}_{6} \mathrm{H}_{5}-\mathrm{CH}_{3}$ & 0.87 & 111 & 4 \\
\hline
\end{tabular}

Table 2. Physical properties of polyurethane

\begin{tabular}{cccc}
\hline Name & Molecular weight (Mw) & Viscosity (cps) & A manufacturing company \\
\hline 972DF & $100,000 \sim 200,000$ & $85,000 \sim 110,000$ & Cytec. Industries Inc. \\
\hline
\end{tabular}

Table 3. Specification of MWNT solutions

\begin{tabular}{ccc}
\hline Name & Solvent & Content of MWNT(\%) \\
\hline I/MWNT & IPA & 3 \\
M/MWNT & MEK & 3 \\
T/MWNT & Toluene & 3 \\
\hline
\end{tabular}


| 72 | 김정현 · 마혜영 · 양성용 · 김승진

Table 4. Manufacturing conditions of PU/MWNT film

\begin{tabular}{|c|c|c|c|c|c|c|c|c|c|}
\hline & $\begin{array}{c}\mathrm{PU} \\
\text { (part) }\end{array}$ & Solvent & $\begin{array}{l}\text { Content of } \\
\text { MWNT solution } \\
\text { (part) }\end{array}$ & $\begin{array}{l}\text { DMF } \\
\text { (part) }\end{array}$ & $\begin{array}{l}\text { MEK } \\
\text { (part) }\end{array}$ & $\begin{array}{l}\text { Drying } \\
\text { Temp. } \\
\left({ }^{\circ} \mathrm{C}\right)\end{array}$ & $\begin{array}{c}\text { Thickness } \\
(\mu \mathrm{m})\end{array}$ & $\begin{array}{c}\text { Measured } \\
\text { Thickness } \\
(\mathrm{mm})\end{array}$ & Remark \\
\hline 1 & \multirow{19}{*}{100} & - & 0 & & 20 & & & 0.021 & \\
\hline 2 & & \multirow{6}{*}{ IPA } & 10 & & 20 & & & 0.026 & \multirow{6}{*}{$\begin{array}{l}\text { Bad dispersion } \\
\text { above } 40 \text { parts }\end{array}$} \\
\hline 3 & & & 20 & & 20 & & & 0.026 & \\
\hline 4 & & & 30 & & 20 & & & 0.026 & \\
\hline 5 & & & 40 & & 20 & & & 0.024 & \\
\hline 6 & & & 50 & & 20 & & & 0.024 & \\
\hline 7 & & & 60 & & 20 & & & 0.021 & \\
\hline 8 & & \multirow{6}{*}{ MEK } & 10 & & 20 & & & 0.026 & \multirow{6}{*}{$\begin{array}{l}\text { Bad dispersion } \\
\text { above } 40 \text { parts }\end{array}$} \\
\hline 9 & & & 20 & & 20 & & & 0.026 & \\
\hline 10 & & & 30 & 10 & 20 & 120 & 150 & 0.025 & \\
\hline 11 & & & 40 & & 30 & & & 0.040 & \\
\hline 12 & & & 50 & & 30 & & & 0.027 & \\
\hline 13 & & & 60 & & 40 & & & 0.038 & \\
\hline 14 & & \multirow{6}{*}{ Toluene } & 10 & & 20 & & & 0.026 & \multirow{6}{*}{$\begin{array}{l}\text { much mat } \\
\text { above } 20 \text { part }\end{array}$} \\
\hline 15 & & & 20 & & 20 & & & 0.031 & \\
\hline 16 & & & 30 & & 30 & & & 0.033 & \\
\hline 17 & & & 40 & & 40 & & & 0.036 & \\
\hline 18 & & & 50 & & 40 & & & 0.032 & \\
\hline 19 & & & 60 & & 50 & & & 0.032 & \\
\hline
\end{tabular}

이루어져 코팅지와 박리 가능한 필름으로 제조 하 였다.

\section{4 물성측정}

\subsection{1 분산용액과 PU/MWNT필름의 UV/VIS/NIR 측정}

분산용액의 분산특성과 분산용액 및 함량별 제조 된 $\mathrm{PU} / \mathrm{MWNT}$ 필름의 분산정도를 확인하기 위하 여 자외선/가시광선/근적외선 분광광도계(UV/VIS/NIR Spectrometer, Varian Inc.)를 이용하여 base line의 기 준을 분산용액일 경우 용매를 기준으로 하고 필름일 경우 공기상으로 두고 $350 \sim 750 \mathrm{~nm}$ 파장영역에서 MWNT 분산용액의 분산성을 측정하는 식 ${ }^{20)}$ 은 아래와 같다.

$$
A b s .(A)=\varepsilon b C
$$

여기서, $\varepsilon$ : molar extinction coefficient, $b$ : path length, $C$ : concentration

\subsection{2 $\mathrm{PU} / \mathrm{MWNT}$ 필름의 전기전도성 측정}

전기전도도는 전도성측정기(KEITHLEY 8009, USA) 와 전위계(KEITHLEY $6517 \mathrm{~B}, \mathrm{USA})$ 를 이용하여 측정 시간(Measure Time, sec.) 15, 상쇄전압량(Offset Voltage, $\mathrm{V})$, 교체전압(Alternating Voltage, V) 50, 측정범위
(Current Range, mA) 20의 조건하에서 부피저항성 과 표면저항성을 측정하였다.

부피저항의 측정식은 아래와 같다.

$$
\rho=\frac{22.9}{\text { thickness of the sample }_{c m}} \times \frac{V}{I} \text { ohm } \cdot \mathrm{cm}
$$

여기서, $22.9 \mathrm{~cm}$ : area of electrode, $V$ : voltage,

$$
I \text { : current }
$$

표면저항의 측정식은 아래와 같다.

$$
\sigma=53.4 \times \frac{V}{I} o h m
$$

여기서, 53.4 : TC Surface, $V$ : voltage, $I$ : current

2.4.3 PU/MWNT 필름의 마찰대전압 및 반감기 측정 필름의 마찰대전압 및 반감기 측정은 마찰대전압 측정기(E.S.T-7, Kanebo, Japan)를 이용하여 습도 $40 \pm 2 \%$, 온도 $20 \pm 2^{\circ} \mathrm{C}$ 상태에서 24 시간 컨디셔닝 후 제조된 필름시료 19종을 울 마찰포를 마찰하는 조건으로 마찰대전압과 반감기를 측정하였다. 마찰포의 종류 에 따라 측정하고자 하는 시료의 대전 서열이 달라 지고 그 결과 동일 시료의 경우에도 정전기적 특성 
치의 차이를 나타낼 수 있으나 ${ }^{19}$ 울 마찰포만을 대 상으로 실험하였다.

\subsubsection{PU/MWNT 필름의 인장특성 측정}

$\mathrm{PU} / \mathrm{MWNT}$ 필름의 역학적 특성은 인장시험기(Testometric MICRO 350)를 이용하여 파지길이 $100 \mathrm{~mm}$ 에 서 인장속도 $100 \mathrm{~mm} / \mathrm{min}$ 으로 측정을 하였다.

\subsubsection{PU/MWNT 필름의 표면특성 측정}

$\mathrm{PU} / \mathrm{MWNT}$ 필름의 표면특성과 분산정도는 비디오 광학현미경시스템(SV-550 Video Microscope System, $\mathrm{SOMETECH}, \mathrm{Korea}$ )을 이용하여 1000 배율로 측정하 였다.

\section{3. 결과 및 고찰}

\section{1 분산용매별 MWNT 용액의 분산성 비교}

분산용액의 분산성을 확인하기 위하여 MWNT를 3종의 용액에 분산시킨 뒤 일주일 경과 후 적외선 가시광선 근적외선 분광광도계를 사용하여 흡광도 를 측정하여 측정된 흡광도 값으로 분산용액별 분 산성을 측정하였다. Fig. 1(a)는 MWNT의 분산용매 가 IPA일 때, 즉 base line이 IPA 순수용매일 때의 IPA/MWNT분산용매의 흡광도 값을 나타냈다. 흡광 도 값은 가시광선영역(305 750nm)사이에서 1.09 1.10 의 값을 나타냈다. Fig. 1(b)는 MWNT의 분산용 매가 MEK일 때(base line은 MEK 순수용매) 흡광도 값 으로 $0.83 \sim 0.85$ 의 값을 나타냈으며 Fig. 1(c)는 MWNT 의 분산용매가 Toluene일 때(base line은 Toluene 순수 용매) 흡광도 값으로 $0.19 \sim 0.21$ 의 값을 나타냈다. 이 3종류의 분산용매에 대한 흡광도 값을 비교하였을 때 Beer-Lambert의 법칙 ${ }^{20)}$ 에 따르면 $A=\varepsilon b C$ 로 여기 서 $\mathrm{C}$ 는 용액의 농도이고, $\mathrm{b}$ 는 빛이 투과하는 셀의 길이, $\varepsilon$ 은 몰흡광계수이다 $(\varepsilon$ 은 몰흡광계수로서 시료 의 성질과 투과하는 빛의 파장에 의존하는 상수). 따라서 셀의 길이 $\mathrm{b}$ 와 몰흡광계수 $\varepsilon$ 이 일정하면 특 정 파장에 대한 흡광도는 용액의 농도와 비례하기 때문에 각 분산용매의 base line을 기반으로 MWNT 의 분산성을 확인하고 용매에 따른 분산성을 비교 하는 지표로 사용 될 수 있으므로 3 용매 중 가장 분산이 잘 이루어진 것은 Fig. 1(a)의 IPA/MWNT 분산용매임을 확인 하였으며 3 종류의 분산용매에 대한 MWNT의 분산성을 보면 IPA $>\mathrm{MEK}>$ Toluene 순서로 분산성이 좋은 것을 알 수 있다.

\section{$3.2 \mathrm{PU} / \mathrm{MWNT}$ 필름내의 탄소나노튜브 분산성 비교}

Fig. 2는 분산용매 종류와 MWNT 분산용매 함량 에 따른 PU/MWNT 필름의 흡광도를 나타냈다. 필 름의 경우 필름의 두께가 균일하고 필름의 조성이
균일할 경우 Beer-Lambert의 법칙으로 분산성의 측 정이 가능할 것이라는 판단으로 $\mathrm{PU} / \mathrm{MWNT}$ 필름 18 종의 흡광도를 측정한 결과 Fig. 2(a)는 IPA/MWNT 분산용매로 함유량이 10 에서 60part로 증가함에 따 라 흡광도 값은 1.2 에서 3.2로 증가함을 나타냈으 며, Fig. 2(b)는 MEK/MWNT 분산용매로 함유량이 10 에서 60part로 증가할 때 흡광도 값도 2에서 5로 증 가함을 보였으며 Fig. 2(c)는 Toluene/MWNT 분산용 매로서 함유량이 10에서 60part로 증가함에 따라 흡 광도 값이 다른 분산용매와 마찬가지로 2에서 3.6으 로 증가함을 보였다. 그러나 각각의 분산용액이 우 레탄내에 일정함량 이상이 되면 분산성이 급격하게 떨어지는 것을 보여 모든 함량에서의 균일한 두께의 필름 제조가 어려웠다. 따라서 각각의 MWNT분산용 액 함유량이 10part일 때 동일한 두께로 제작된 필 름의 흡광도를 비교하였을 때 분산용매가 IPA일 경 우 $0.7 \sim 1.2, \mathrm{MEK}$ 의 경우 $0.79 \sim 1.41$, Toluene의 경우 2.17 3.14로 우레탄으로 제조된 필름내에서 분산

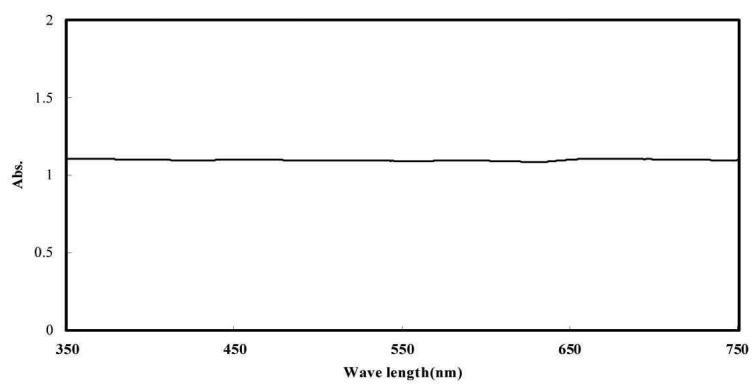

(a)

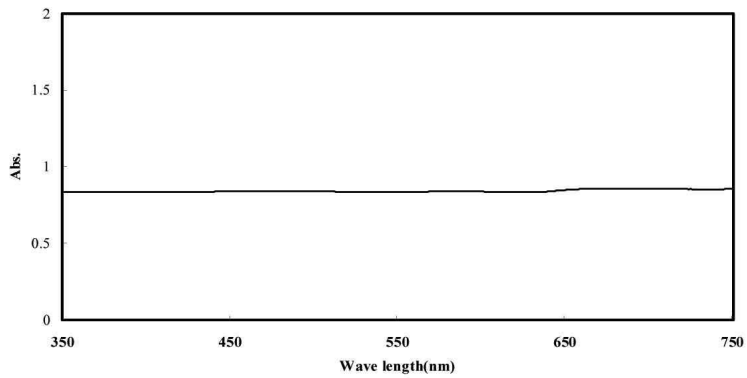

(b)

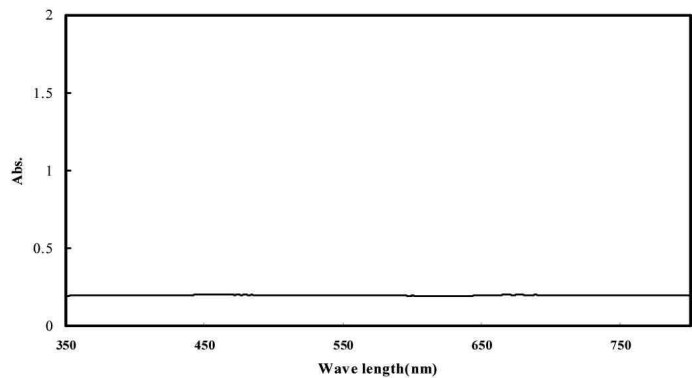

(c)

Fig. 1. Absorbance of MWNT dispersion solutions according to the dispersion solvent.

(a) surface resistivity (b) volume resistivity 
성을 비교한다면 $\mathrm{MEK}>\mathrm{IPA}>\mathrm{Toluene}$ 순서임을 확인하 였다. IPA분산용액과 MEK분산용액의 경우 함량이 40part를 넘기면서 우레탄 내에서의 분산성이 떨어 지기 시작했으며 Toluene의 경우는 Toluene의 과도한 휘발성 때문에 분산용액의 함량이 10 20part를 넘기 면서 분산성이 떨어져 과도한 엉김현상까지 나타났 다. 따라서 MWNT의 분산용매로 Toluene의 사용은 다소 무리가 있음을 확인하였다.

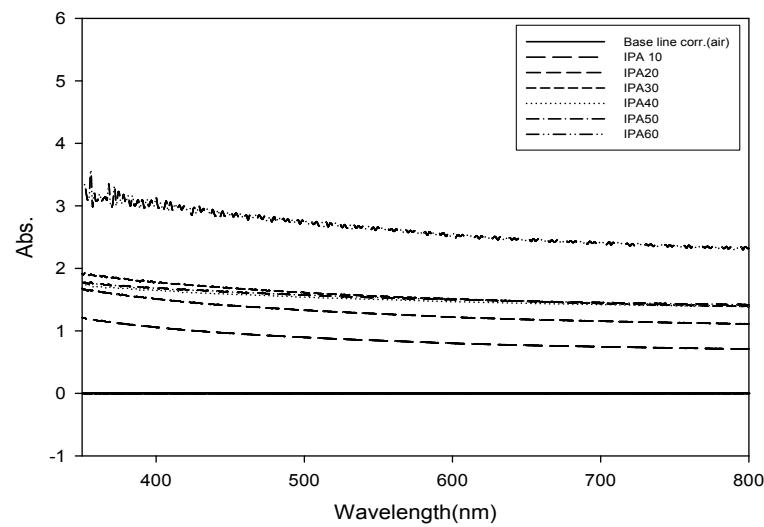

(a)

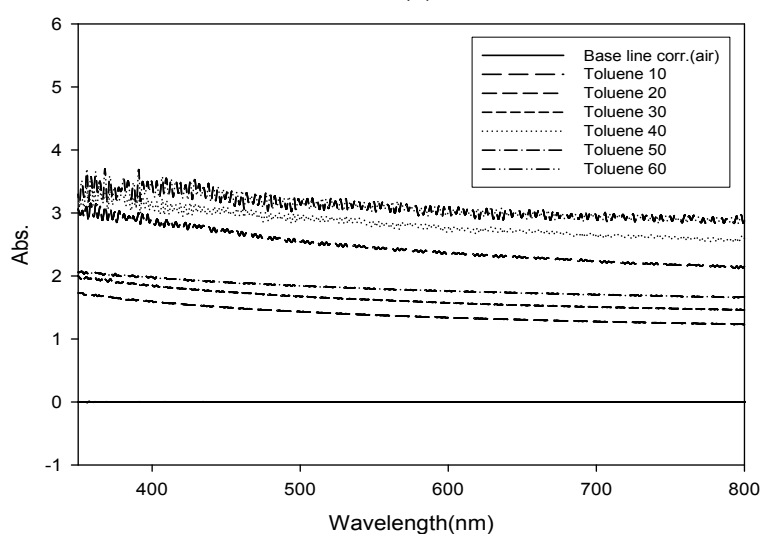

(b)

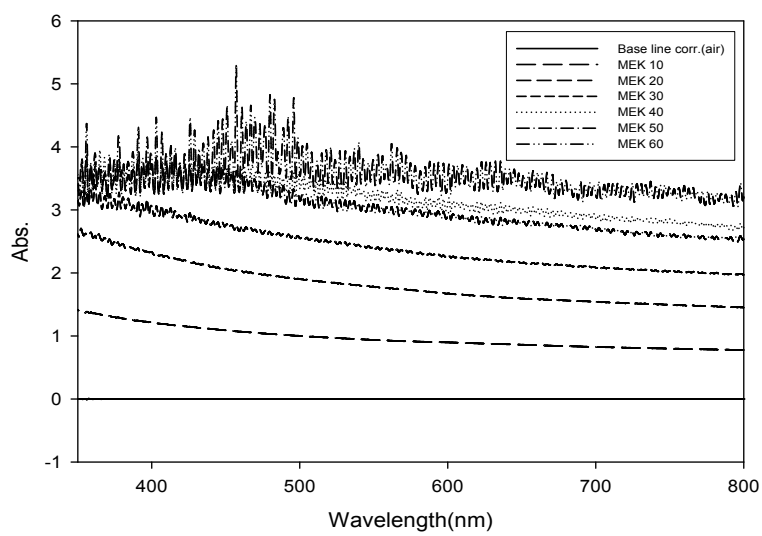

(c)

Fig. 2. Absorbance of PU/MWNT film according to the dispersion solutions.
(a) IPA/MWNT (b) MEK/MWNT
(c) Toluene/MWNT

\section{3 전기전도도}

Fig. 3(a)와 (b)는 분산조건에 따른 PU/MWNT 필 름의 표면 전기저항성과 부피전기저항성을 나타냈 다. Fig. 3(a)에서 MWNT가 함유되지 않은 PU 필름 의 표면 저항성 측정결과는 $2.4 \times 10^{16} \sim 3.7 \times 10^{17}(\mathrm{ohm})$ 이고 Fig. 3(b)에서의 MWNT가 함유되지 않은 PU 필름의 부피저항은 $3.2 \times 10^{14}(\mathrm{ohm} \cdot \mathrm{cm})$ 으로 표면과 부피저항 모두 전기전도성을 거의 띄지 않는 것 ${ }^{21)}$ 으로 확인되었다.

Fig. 3(a)에서 함유량이 20part가 되면 표면저항값 이 $4.6 \times 10^{8} \mathrm{ohm}$ 으로 $10 \mathrm{part}$ 일 때 $1.6 \times 10^{16} \mathrm{ohm}$ 에서 큰 폭으로 낮아지는 것을 볼 수 있다. 그러나 함유 량이 30 이상 60 이 되어도 표면저항값은 $6.0 \times 10^{8} \sim$ $8.5 \times 10^{7} \mathrm{ohm}$ 으로 크게 변화가 없음을 보였다. 따라 서 3종의 분산용액의 함량이 20part 30part정도가 적당함을 보였으며 함량을 높여도 표면저항값에 있 어서의 차이는 크게 생기지 않음을 보였다. 그리고 20part에서 IPA/MWNT의 표면저항값이 MEK/MWNT

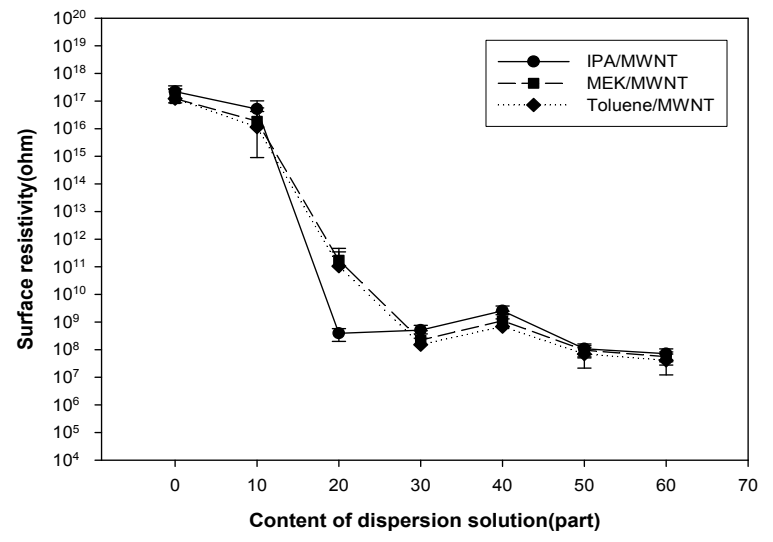

(a)

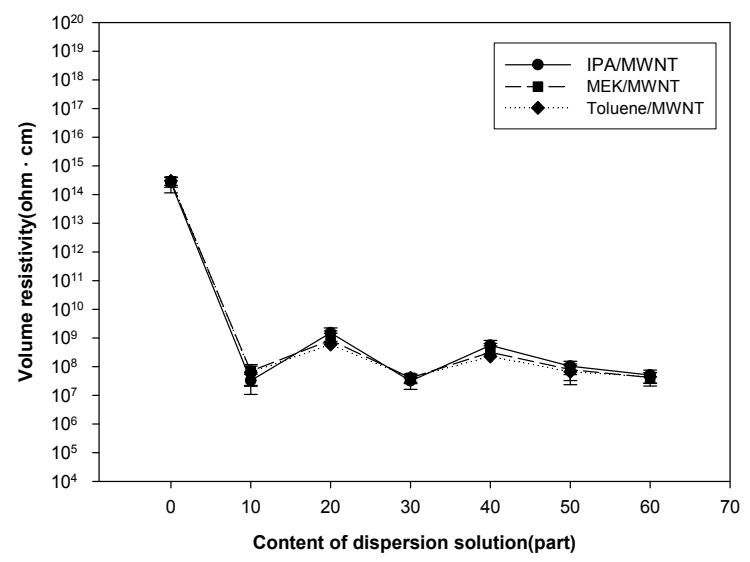

(b)

Fig. 3. Surface resistivity and volume resistivity of MWNT/PU film according to the MWNT dispersion solution and its contents.

(a) surface resistivity (b) volume resistivity 
와 Toluene/MWNT보다 크게 낮은 값을 보임으로서 IPA용매가 상대적으로 MEK와 Toluene보다 우수한 전기전도성을 보인다고 사료된다.

Fig. 3(b)에서 MWNT분산용액의 함유량이 10part 가 되면 부피저항값이 $1.1 \times 10^{8} \sim 4.7 \times 10^{7} \mathrm{ohm} \cdot \mathrm{cm}$ 으로 $\mathrm{MWNT}$ 가 함유되지 않은 PU필름의 부피저항치인 $1.6 \times 10^{16} \mathrm{ohm} \cdot \mathrm{cm}$ 보다 큰폭으로 낮아지는 것을 볼 수 있다. 그러나 부피저항 역시 표면저항과 마찬가지 로 함유량이 20part이상 60part가 되어도 부피저항 값은 $1.0 \times 10^{8} \sim 6.0 \times 10^{7} \mathrm{ohm} \cdot \mathrm{cm}$ 로 함유량 $10 \mathrm{part}$ 일때 의 부피저항값과 크게 변화가 없음을 나타냈다. 그 리고 10part일 때 용매에 따른 부피저항치는 IPA가 $\mathrm{MEK}$ 와 Toluene보다 약간 낮은 값을 보임을 확인 할 수 있었다.

\section{4 마찰대전압과 반감기}

Fig. 4(a), (b), (c)는 분산조건에 따른 PU/MWNT 필름의 마찰대전압과 wool fabric의 마찰에 대한 반 감기를 나타낸다. Fig. 4(a)의 분산용액이 IPA일 경우 IPA/MWNT 용액의 함유량이 10part 일 경우 초기 마 찰대전전압이 $0.59 \mathrm{kv}, 20 \mathrm{part}$ 일때는 초기 마찰대전 압이 $1.72 \mathrm{kv}$ 였으며 측정 시간 $60 \mathrm{sec}$ 가 지날 때 까 지 마찰대전압은 $0.58 \mathrm{kv}$ 와 $1.63 \mathrm{kv}$ 로 거의 떨어지지 않았으나 IPA/MWNT 분산용액의 함량이 30part 일 경 우 초기 마찰대전압이 $0.33 \mathrm{kv}$ 였으나 $10 \mathrm{sec}$ 뒤 $0.05 \mathrm{kv}$ 로 떨어지고 $30 \mathrm{sec}$ 뒤 $0.00 \mathrm{kv}$ 로 측정되어 마찰로 인 한 정전기에 대한 반감기는 $2.8 \mathrm{sec}$ 인 것을 확인하 였다. 또한 IPA/MWNT 함유량이 40이상이면 반감 기가 0 으로 완벽한 대전방지가 되는 것으로 확인되 었다. Fig. 4(b) MEK의 경우는 $\mathrm{MEK} / \mathrm{MWNT}$ 분산용 액의 함유량이 $10 \mathrm{part}$ 일 때 마찰대전압은 $2.31 \mathrm{kv}$ 이고 측정시간 $60 \mathrm{sec}$ 가 지날 때 까지 마찰대전압은 $2.24 \mathrm{kv}$ 로 거의 떨어지지 않았으나 함유량이 $20 \mathrm{part}$ 가 되 면 초기 마찰대전압은 $0.06 \mathrm{kv}$ 이지만 $30 \mathrm{sec}$ 후 마찰 대전압은 $0.02 \mathrm{kv}$ 로 측정되어 평균 반감기는 $5.60 \mathrm{sec}$ 인 것으로 확인되었다. $\mathrm{MEK}$ 분산용액 역시 함유량 이 30 part 이상이 되면 반감기는 0 로 측정되어 완 벽한 대전방지가 되는 것으로 확인되었다. Fig. 4(c) Toluene의 경우는 함유량 10 20part일 경우는 마찰 대전압은 $10.83 \mathrm{kv} \sim 3.70 \mathrm{kv}$ 로서 이에 대한 반감기는 측정되지 않았으나 함유량이 30part 이상이 되면 마찰대전압에 대한 반감기는 0 로 측정되어 다른 두 가지 용매들과 같이 대전방지가 되는 것으로 확인 되었다. 여기서 Fig. 3(a)의 표면 전기저항은 IPA> Toluene $>\mathrm{MEK}$ 순으로 낮은 값을 가지나 마찰대전 압은 $\mathrm{MEK}>\mathrm{IPA}>\mathrm{Toluene}$ 순으로 낮은 값을 나타내 고 있으며 마찰대전압 발생량과 표면 전기저항의 크기는 완전히 일치하지 않는 것을 알 수 있다. 이
는 시료내 각각 다른 수분함유량 등의 차이에 의한 결과로 사료된다.

\section{5 인장특성}

Fig. 5는 분산조건에 따른 PU/MWNT 필름의 절 단강도를 나타낸다. 분산용매가 IPA일 경우 32.5

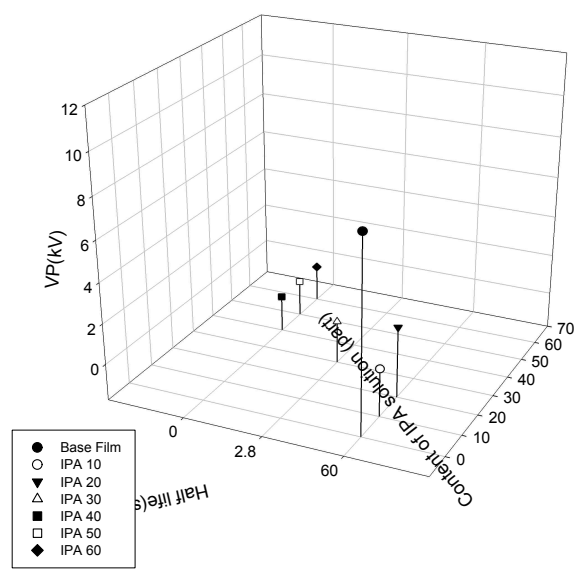

(a)

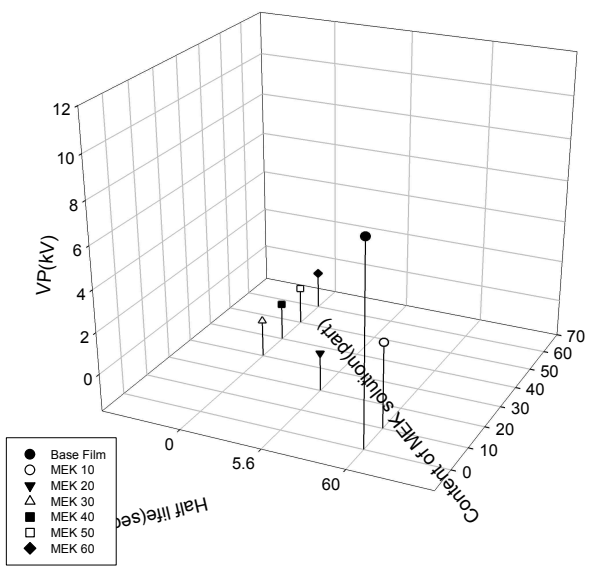

(b)

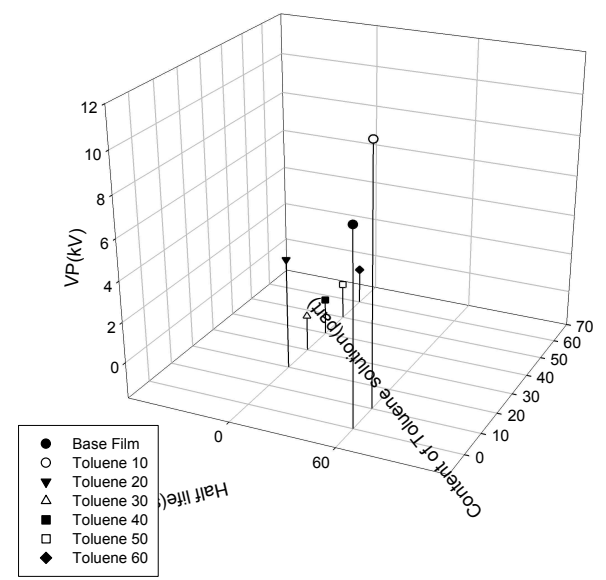

(c)

Fig. 4. Triboelectricity of PU/MWNT film according to the dispersion solutions.
(a) IPA/MWNT (b) MEK/MWNT (c) Toluene/MWNT 
$24.1 \mathrm{~kg}_{\mathrm{f}} / \mathrm{mm}^{2}$, MEK일 경우 $18.7 \sim 17.0 \mathrm{~kg}_{\mathrm{f}} / \mathrm{mm}^{2}$ Toluene 일 때 절단강도 값은 $16.6 \sim 8.3 \mathrm{~kg}_{\mathrm{f}} / \mathrm{mm}^{2}$ 의 분포를 보 이며 3 종류의 분산용액 중 IPA의 경우 분산성이 떨어지지 않는 40part 함량까지는 함유량이 증가함 에 따라 절단강도가 감소하는 경향을 보였다. 이것 은 $\mathrm{CNT}$ 복합재의 기계적 물성은 $\mathrm{CNT}$ 가 복합재 내 에서 충분한 분산이 이루어지지 않을 경우 $\mathrm{CNT}$ 다 발이 발생하고 이 다발의 내부는 복합재와 충분한 접촉면을 갖기 어려워 쉽게 뭉치는 현상을 유발하 여 분산효과와 배향효과를 감소시키게 되고 결과적 으로 복합재에 가해지는 응력에 대해 복합재가 응 력을 분산 할 수 있는 능력이 떨어져 기계적 물성 의 저하를 초래한다 ${ }^{22,23)}$ 는 연구결과들과 동일한 결 과를 보이고 있으나 3종의 분산용매를 비교 할 때 동 일함량에서의 절단강도값을 비교해보면 IPA $>\mathrm{MEK}>$ Toluene 순으로 측정이 되고 함량에 따른 절단강도 의 감소현상도 IPA에서 뚜렷하게 관찰됨으로써 분 산성도 동일 순서로 좋은 것임을 확인하였다.

Fig. 6은 분산조건에 따른 $\mathrm{PU} / \mathrm{MWNT}$ 필름의 절 단신도를 나타냈다. 분산용매가 IPA일 경우 절단신 도 값은 $195.6 \sim 125.8 \%$, MEK일 경우 202.2 177.7\%, Toluene일 경우의 절단신도 값은 $189.3 \sim 74.3 \%$ 로 분 포하며 IPA의 경우 분산성이 떨어지지 않는 40part 함량까지 함유량이 증가함에 따라 절단신도의 규칙 적인 감소경향을 보이는 것을 볼 수 있으며 이러한 결과에서 역시 IPA의 분산성이 $\mathrm{MEK}$ 와 Toluene에 비해 양호함을 확인 할 수 있다. 그리고 3 가지 분산 용매들의 절단신도 값을 비교해 볼 때 함량에 따라

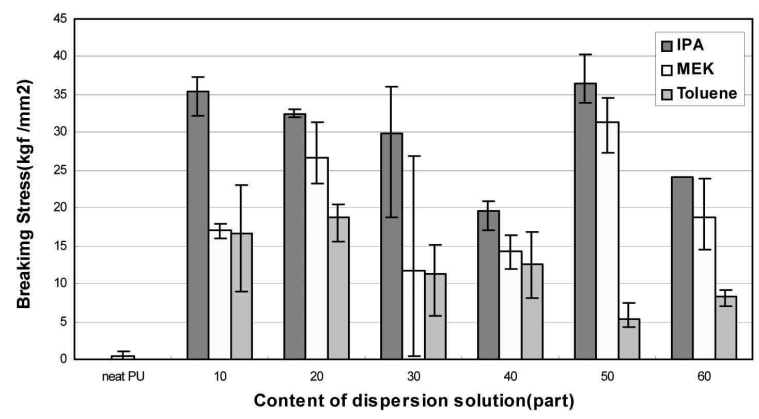

Fig. 5. Breaking stress of PU/MWNT films.

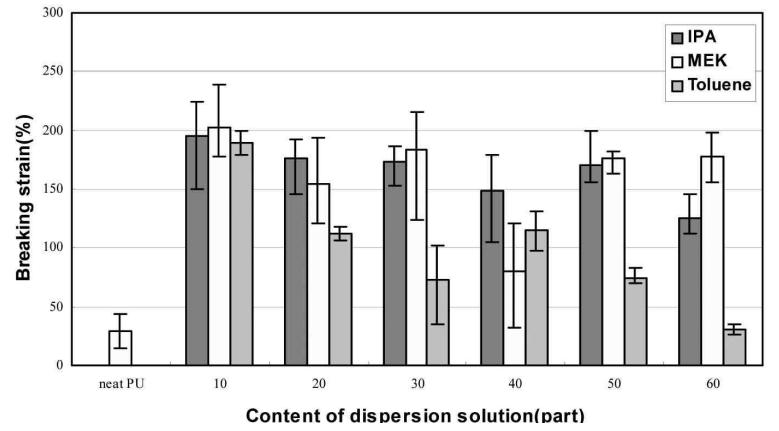

Fig. 6. Breaking strain of PU/MWNT films.

안정되면서 높은 신도를 보이는 것은 역시 IPA용 매라는 것을 확인 할 수 있다.

\section{6 표면특성}

Fig. 7은 PU/MWNT 필름의 표면을 비디오 현미 경 시스템을 이용하여 1000 배율로 측정한 결과를 나타냈다.

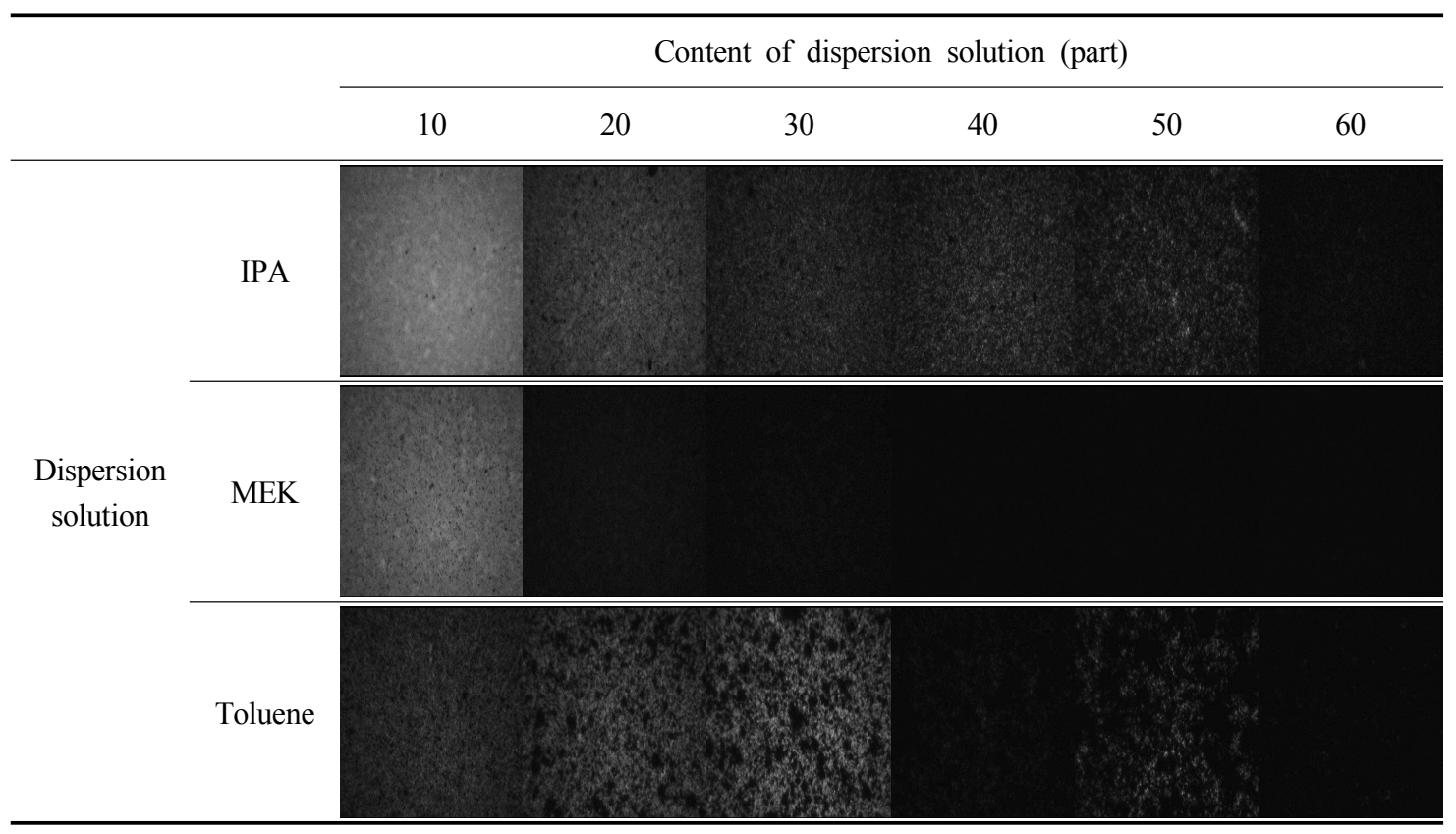

Fig. 7. Surface images of the PU/MWNT film according to the dispersion conditions. 
제조된 $\mathrm{PU} / \mathrm{MWNT}$ 필름은 MWNT 함유량과 분산 용매에 따라 분산성의 차이를 나타내는 것을 볼 수 있었다. Fig. 7에서 볼 수 있듯이 분산용매 IPA의 경우 상대적으로 $\mathrm{MEK}$ 와 Toluene 분산용매에 비해 분산용액 함량에 따른 $\mathrm{MWNT}$ 의 분산이 균일하게 잘 분산된 것을 확인 할 수 있다. 반면에 Toluene 의 경우 20 과 30 part에서 $\mathrm{MWNT}$ 의 뭉침현상을 보 였고 $\mathrm{MEK}$ 의 경우 40part 함량부터 분산성이 떨어 짐이 확인되었다.

\section{4. 결 론}

본 연구에서는 여러 가지 분산 용매에 탄소나노 튜브를 분산시켜 각 용매별 분산용액의 함량을 변 화시켜 PU/MWNT필름을 제조하였으며, 제조된 필 름의 특성을 측정하고 분석한 결과 다음과 같은 결 론을 얻었다.

1. 3종의 분산용액 IPA, MEK, Toluene에 MWNT를 분산하여 흡광도를 측정한 후 분산용매에 따른 MWNT분산용액의 분산성을 비교하였을 때 IPA> $\mathrm{MEK}>\mathrm{Toluene}$ 순서로 분산성이 좋음을 확인하였다.

2. 3종의 분산용액을 함유한 PU/MWNT필름의 흡광 도를 측정하였을 때 $\mathrm{MEK}>\mathrm{IPA}>\mathrm{Toluene}$ 순으로 분산성이 좋음을 확인하였으며 매트릭스인 폴리 우레탄 $100 \mathrm{~g}$ 대비 분산용액의 함량은 30part이하 를 함유하는 것이 필름을 제조하기에 가장 좋은 함량임을 확인하였다. 그리고 Toluene을 분산용 매로 사용할 경우 Toluene의 과도한 휘발성으로 인한 우레탄과의 엉김현상이 발생하여 필름제조 MWNT 분산용액으로 적절치 못함을 확인하였다.

3. 전기 전도도의 경우 표면저항값은 분산용액의 함유량이 30 이상이면 $6.0 \times 10^{8} \sim 8.5 \times 10^{7} \mathrm{ohm}$ 으로 함 량이 증가하여도 그 값은 크게 변화가 없음을 보 여 분산용액의 우레탄 내 함량은 20part 30part이 하가 적절한 함유량임을 확인하였으며 특히 분 산용액이 IPA일 경우 분산용액 20part 함유량에 서 표면저항값은 $10^{8} \mathrm{ohm}$ 정도로서 다른용매에 비 해 가장 낮은 값을 보였으며, 부피저항값은 10part 에서 다른 용매에 비해 가장 낮은 값인 $10^{7} \mathrm{ohm} \cdot \mathrm{cm}$ 치를 보였다.

4. 표면 대전압과 반감기 측정을 하였을 때는 3 종 분산용액 모두 함유량이 40 이상이면 대전되는 것으로 확인되었으며 특히 IPA 분산용액의 경우 는 함유량 30 이상 일 때 반감기가 2.8 초로 가장 빨리 대전 되는 것으로 확인되었다.

5. 필름의 물리적 특성에서 절단강도와 절단신도 모 두 IPA용매의 경우 40part 함량까지 MWNT 분산 용액의 함량이 증가함에 따라 감소하는 경향을
나타냈으며 3 종의 분산용액을 비교하였을 때 절 단강도에서는 분산용액이 IPA일 경우 가장 높은 절단강도값을 보였으며 절단신도에서도 분산용액 이 IPA일 때 가장 안정되면서도 높은 절단신도 값을 보였다.

6. PU/MWNT 필름의 표면사진 분석결과 IPA/MWNT 분산용액으로 만들어진 $\mathrm{PU} / \mathrm{MWNT}$ 필름에서 분 산용액 함량에 따른 MWNT의 균일한 분포를 확 인 할 수 있었다.

따라서 분산용액은 IPA로 사용하고 분산용액함 유량을 20part이상 30part이하로 하여 PU/MWNT필 름을 제조 하였을 경우 전기저항, 대전압 및 반감 기, 표면특성 등에서 정전 · 방전발포필름의 1-skin 층으로 사용 적합함을 확인하였다.

$$
\text { 감사의 글 }
$$

본 연구는 교육과학기술부와 한국연구재단의 지 역혁신인력양성사업으로 수행된 연구결과로 관계 기관에 감사드린다.

\section{참고문헌}

1. G. W. Lee and J. T. Han, Dispersion of Carbon Nanotubes(CNTs) and CNT-based Transparent Conductive Films, KIC News, 10(4), 8-19(2007).

2. D. O. Kim and J. D. Nam, Polymeric Carbon Nanotube Nanocomposites, Prospectives of Industrial Chemistry, 9(6), 3-13(2006).

3. J. Liu, A. G. Rinzler, H. J. Dai, J. H. Hafner, R. K. Bradley, P. J. Boul, A. Lu, T. Iverson, K. Shelimov, C. B. Huffman, F. Rodriguez Macias, Y. S. Shon, T. R. Lee, D. T. Colbert, and R. E. Smalley, Fullerene Pipes, Science, 280, 1253-1256 (1998).

4. S. H. Kim, X. Wang, S. C. Lee, and B. G. Min, Rhelogical Properties and Eletrospinning of PVA/ CNT Aqueous Solution, Textile Science and Engineering (J. Korean Fiber Society), 43, 251-256(2006).

5. J. W. Kim, Y. C. Jung, and J. W. Cho, Carbon Nanotube-Polyurethane Nanocomposites Having Characteristics of Electroactive Shape Recovery, Textile Science and Engineering(J. Korean Fiber Society), 42, 270-276(2005)

6. J. Y. Won, M. H. Jee, S. H. Park, Y. G. Jeong, and D. H. Baik, Preparation and Characterization of CNT-coated Conductive Fibers, Textile Science and Engineering(J. Korean Fiber Society), 46, 1-7 (2009). 
7. M. Jung and J. H. Cho, Mechanical, Thermal and Electrical Properties of Carbon Nanotube-Polyurethane Nanocomposites, Textile Science and Engineering(J. Korean Fiber Society), 41, 73-79(2004).

8. M. S. Kang, S. M. Kwon, D. Y. Kim, H. S. Kim, and H. J. Jin, Preparation of Electrospun Poly (hexamethylene sebacamide)/Multiwalled Carbon Nanotube Nanofibrous Membranes, Textile Science and Engineering(J. Korean Fiber Society), 45, 159165(2008).

9. H. Kitano, K. Tachimoto, and Y. Anraku, Functionalization of Single-walled Carbon Nanotube by the Covalent Modification with Polymer Chains, J. Colloid Interface Sci., 306, 28-33(2007).

10. S. Musso, S. Porro, M. Vinante, L. Vanzetti, R. Ploeger, M. Giorcelli, B. Possetti, F. Trotta, C. Pederzolli, and A. Tagliaferro, Modification of MWNTs Obtained by Thermal- CVD, Diamond \& Related Materials, 16, 1183-1187(2007).

11. T. Saito, K. Matsushige and K. Tanaka, Chemical Treatment and Modification of Multiwalled Carbon Nanotubes, Physical B, 323, 280-283(2002).

12. A. Hirsch, Functionalization of Single-Walled Carbon Nanotubes, Angew Chem. Int. Ed., 41, 1853-1859 (2002).

13. M. Olek, M. Hilgendorff, and M. Giersig, A Simple Route for the Attachment of Colloidal Nanocrystals to Noncovalently Modified Multiwalled Carbon Nanotubes, Colloids and Surfaces A: Physicochem Eng. Aspects, 292, 83-85(2007).

14. I. Kumar, S. Rana, C. V. Rode, and W. Cho, Functionalization of Single-Walled Carbon Nanotubes with Azides Derived from Amino Acids Using Click Chemistry, Journal of Nanoscience and Nanotechnology, 8, 1-6(2008).

15. Y. Noguchi, T. Fujigaya, Y. Niidome, and N. Nakashima, Single-walled Carbon Nanotubes/DNA Hybrids in Waterare Highly Stable, Chemical Physics Letters, 455, 249-251(2008).

16. K. S. Park, S. J. Kim, J. H. Kim, J. H. Park, and O. K. Kwon, Modification of Carbon Nanotube for the Improvement of Dispersion and the Dispersion Characteristics of Carbon Nanotube in Polyurethane, Textile Coloration and Finishing(J. of Korean Soc. Dyers \& Finishers), 22(1), 43-50(2010).

17. J. H. Kim, J. H. Park and S. J. Kim, The Physical Property of MWNT/PU Composite Films, Textile Coloration and Finishing(J. of Korean Soc. Dyers \& Finishers), 22(3), 246-256(2010).

18. J. H. Park, J. H. Kim and S. J. Kim, Manufacturing and Characteristics Analysis of PU/MWNT Composite Film for Forming, Textile Coloration and Finishing(J. of Korean Soc. Dyers \& Finishers), 22(4), 362-372(2010). 